\title{
Government Control and Privatized Firms' Performance: Evidence from Vietnam
}

\author{
Manh Hoang NGUYEN', Quy Thi VO²
}

Received: August 01, 2020 Revised: September 06, 2020 Accepted: September 11, 2020

\begin{abstract}
To enhance the performance of privatized firms and state-owned enterprises, Vietnamese government set up a specialized monitoring body named State Capital Investment Corporation (SCIC) in 2006 to supervise their performance. This motivated us to conduct this study to investigate the effective control of SCIC on privatized firms' performance. We collected the annual reports of 500 non-financial privatized firms listed on HSX and HNX during the period from 2007 to 2017 from Thomson Reuters. Observations with missing values were removed and trimming outliers were implemented resulting in a dataset comprising of 4146 firm-year observations. We applied a quadratic regression model of state ownership on firms' performance, and applied the method of Baron and Kenny (1986) to test the moderating effect of SCIC control. To fix "selection bias" that may occur and result in endogeneity of moderator $(M)$, we utilized the PSM technique to analyze the marginal effect of the moderator (SCIC) on privatized firms' performance. Our findings indicate a positive moderating role of SCIC on the relationship between the state ownership and firms' performance. This implies that there is a positive effect of liberating the management of the private firms from government control, which also means that lesser the intervention of government in the day to day operational activities of a private firm, better the performance of a privatized firm is.
\end{abstract}

Keywords: State Ownership, Privatization, Firm Performance, Vietnam

JEL Classification Code: G30, L32, L33, P31

\section{Introduction}

According to agency theory, a good corporate governance mechanism would alleviate agency problem and separation of ownership and control in companies creates agency problems, the conflicts of interests between shareholders and management brings a positive impact on firm performance and value (Denis, 2001). Many researchers have asserted that a firm's ownership structure is one of the principal

${ }^{1}$ First Author. PhD Candidate, [1] School of Business, International University, Vietnam National University, Ho Chi Minh City, Vietnam [2] Nguyen Tat Thanh University, Ho Chi Minh City, Vietnam.

Email: manhhoang@ntt.edu.vn

${ }^{2}$ Corresponding Author. Lecturer, School of Business, International University, Vietnam National University, Ho Chi Minh City, Vietnam [Postal Address: Quarter 6, Linh Trung Ward, Thu Duc District, Ho Chi Minh City, 700000, Vietnam] Email: vtquy@hcmiu.edu.vn

(c) Copyright: The Author(s)

This is an Open Access article distributed under the terms of the Creative Commons Attribution Non-Commercial License (https://creativecommons.org/licenses/by-nc/4.0/) which permits unrestricted non-commercial use, distribution, and reproduction in any medium, provided the original work is properly cited. instruments of corporate governance (Abdallah \& Ismail, 2017; Aguilera \& Jackson, 2010; He, Li, \& Tang, 2012; Hu \& Izumida, 2009; Li, McMurray, Sy, \& Xue, 2018; Loch, Marcon, Pruner Da Silva, \& Xavier, 2018; Panda \& Leepsa, 2017; Porta, Lopez-De-Silanes, \& Shleifer, 1999).

Many studies conducted in the 1990s asserted that stateowned enterprises (SOEs) are less efficient than private firms in most countries and regions, and privatization has been widely accepted as a critical solution for improving SOEs' performance and value. However, several governments still retain large ownership proportion in the privatized firms (Bortolotti \& Faccio, 2009), and privatized firms with the pursuit of multiple goals contradicting each other and being affected by political interference have faced serious agency problem, according to Peng, Bruton, Stan, and Huang (2016). With a weak governance mechanism, privatized firms may be less transparent and accountable (Chen, 2013; Chien-Chung, 2012; Kamal, 2010; Kim \& Chung, 2018; Nurgozhayeva, 2017; Peng et al., 2016; Wong, 2004). Therefore, privatized governments have been looking for a governance model which could mitigate the agency problem in privatized firms, because it clearly remains unresolved. (Wang \& 
Judge, 2012), and Vietnam is not an exception. In fact, many privatized governments have realized about the need to form a government agent holding, a function to reduce conflicting objectives called and it is called a State-Owned Holding company $(\mathrm{SOH}) . \mathrm{SOH}$ is an intermediary agent that acts like a direct investment holding arm of governments (Kim $\&$ Chung, 2018; Sam, 2007). Acting as a strategic investor with large ownership proportion in privatized which results in mitigating agency problem (Sam, 2013). According to Kuznetsov and Murav'ev (2001); Yin Sam (2010), Kim and Chung (2018), strategic investors theoretically have stronger incentives to maximize firm performance. The presence of $\mathrm{SOH}$ control is assumed as a better governance mechanism to improve privatized firms' corporate governance and a firm's performance.

The objective of this study is to test the moderating role of $\mathrm{SOH}$ on the relationship between residual state ownership and the performance of privatized firms. The results of this study provide the empirical evidence to policy makers for evaluating the efficiency of SOH's functions which relates to increasing the effectiveness of state-owned capital invested in privatized firms by applying an effective monitoring mechanism.

Our study utilizes a linear regression model with a quadratic functional form and propensity score matching (PSM) technique to analyze the moderating role of $\mathrm{SOH}$ as well as the marginal impact of this factor on privatized firms' performance by using the dataset collected from all privatized firms listed on Ho Chi Minh Stock Exchange (HSX) and Hanoi Stock Exchange (HNX) during 2007 to 2017. This study's results indicated that $\mathrm{SOH}$ control variable positively moderates the relationship between residual state ownership and privatized firms' performance. This paper is structured into seven main sections. Section 2 presents literature review to develop research hypothesis. Section 3 discusses the methodology used in the study. Section 4 presents empirical results of the study. Finally, discussion and conclusion are provided in Sections 5 and 6, respectively.

\section{Literature Review}

Most scholars have explained the negative impacts of state ownership on firm performance via the light of agency theory initiated by Jensen and Meckling (1976). State ownership is considered as a source of inefficiency of SOEs' performance which mainly arises due to two types of agency conflicts. The first is the agency conflict between non-state owner and state owners who prefer to have socio-political objectives to maximize the shareholders' wealth, which is the priority objective of non-state shareholders. This type of conflict is well documented in the literature (Bennedsen, 2000; Bo, Li, \& Toolsema, 2009; Boycko, Shleifer, \& Vishny, 1996; Laffont \& Tirole, 1991; Li \& Xia, 2008). The second is the agency conflict between managers, government officials being representatives of state capital invested in privatized firms and citizens who are the true owners of state capital. Given people's self-interest motive, government officialmanagers tend to pursue their own interests rather than the interests of citizens (Megginson, 2017; Megginson \& Netter, 2001; Shleifer \& Vishny, 1997). Further, the agency problem is signified as there is no clear financial objectives guiding their decisions and a weak performance-compensation link in privatized firms (Liu, Wang, Zhang, \& Zhang, 2012; Sheshinski \& López-Calva, 2003). The agency problems may result in inefficiency in the business operations of the privatized firms' and consequently there will be low return on capital invested in SOEs and/or privatized firms.

Many countries with privatized governments have established monitoring body with the aim to enhance the investment effectiveness of state capital in privatized firms. For instance, Singapore established Temasek in 1974; Austria formed Industry-Holding Stock Corporation in 1986; Malaysia established Khazanah Nasional Berhad (KNB) in 1994; Bhutan established Druk Holdings and Investments in 2007, Kazakhstan established Samruk- Kazyna in 2008, and Vietnam set up State Capital Investment Corporation (SCIC) in 2006. The effective functioning of these bodies is still questionable, except the effectiveness of Temasek and KNB. These two bodies have been under popular investigations of academic researchers. The efficient functioning of $\mathrm{SOH}$ is measured by the outperformance of privatized firms with $\mathrm{SOH}$ ownership compared to those without $\mathrm{SOH}$ investment.

Vietnamese government started privatization called equitization since 1990s, and the process has not yet been completed. Although it does not have much noticeable progress, the positive effect of privatization on firm performance is widely accepted with plenty of empirical evidence provided from Loc, Lanjouw, and Lensink (2006); Ngo, Nonneman, and Jorissen (2015). These findings are consistent with other researches on privatization done in a global context (Boubakri, Cosset, \& Guedhami, 2005; Megginson, Nash, \& Randenborgh, 1994; Souza, Megginson, \& Nash, 2005; Souza \& Megginson, 1999). Till recently the state sector played a dominant role in the economy and accounts for approximately one-third of the total Gross Domestic Product (GDP) of the country (Nem Singh \& Chen, 2018). As the return on investments of state capital have been uncertain and also inefficient, the Vietnamese government wanted to enhance the monitoring of the return on investment by establishing SCIC and assigning it with two primary responsibilities, which was maximizing the market value of state capital in privatized firms under its control, and liquidating the state capital if necessary. Apart from SCIC, there are privatized firms directly controlled by the central government, local governments, and line ministries. Transferring the management of SOEs (firms with the state capital) to SCIC, aims to reduce governmental intervention in the day-to-day business operation of SOEs 
and consequently, promote 'market mechanisms' among SOEs (Nguyen, Nguyen, \& Nguyen, 2012). Therefore, the need to conduct the study on the moderating effect of SCIC on Vietnamese privatized firms' performance motivated us to conduct this study.

Economists argue that the partial ownership of the privatized firms may bring about both beneficial and detrimental effects on firm performance (Boubakri, El Ghoul, Guedhami, \& Megginson, 2018). Academic scholars assume that institutional contexts matter when assessing the impact of state ownership on a firm's performance. Megginson and Netter (2001) assumed that the impact of state ownership on firm performance may depend on the level of market failure in specific cases. Thus, the impact of state ownership on privatized firm performance may be significantly moderated by various factors. Scholars recommend that state investors should not be considered as a homogeneous group since they belong to a different group and they tend to pursue very different types of objectives (Holland, 2019; Tirole, 1994). These arguments support the development of this hypothesis. This is the main hypothesis which was tested in our study.

H1: SCIC's monitoring enhances the positive impact of residual state ownership on firm's performance.

\section{Methodology}

\subsection{Model Specification}

\subsubsection{Quadratic Regression with Interactive Terms}

We applied a quadratic regression model of state ownership $(S O)$ on firm performance $(F P)$ since there is an evidence of quadratic relationship between the two variables (Ngo, Nonneman, \& Jorissen, 2014; Tian \& Estrin, 2008; Wei, Xie, \& Zhang, 2005).

Next, we follow the idea of Baron and Kenny (1986) in testing the moderating effect of a variable as following:

Firstly, we test the effect of independent $S O$ on dependent $F P$. The test result is expected that the relationship does exist and it is significant.

$$
F P=\alpha+\beta_{1} S O+\beta_{2} S O^{2}+\boldsymbol{X} \boldsymbol{\beta}_{3}+\varepsilon .
$$

where $F P$ is firm's performance; $S O$ is state ownership; $\mathrm{SO}^{2}$ is square of state ownership; $\boldsymbol{X}$ includes control variables comprising of firm size, firm leverage, managerial ownership, board ownership, domestic institutional ownership, foreign institutional ownership, industry dummies, year dummies and exchange dummies. $\beta_{\mathrm{s}}$ are coefficients, and $\varepsilon$ is an error term.

Secondly, if the relation (1) exists and is statistically significant, the moderating effect of $M$ is entered into the regression equation model as follows:

$$
\begin{aligned}
& F P=\alpha+\beta_{1} S O+\beta_{2} S O^{2}+\beta_{3} M+\beta_{4} S O \times M+\beta_{5} S O^{2} \\
& \quad \times M+\boldsymbol{X} \boldsymbol{\beta}_{5}+\varepsilon .
\end{aligned}
$$

where $M$ is the variable for the $\mathrm{SOH}$. The test of moderation is operationalized by the product term of $S O \times M$ (the multiplication of state ownership and the moderating variable) and $S^{2} \times M$ (the multiplication of the square of state ownership and the moderating variable).

The moderating effect is validated if $\beta_{4}$ and $\beta_{5}$ are significant. Then one could conclude that the moderator variable $M$ moderates the relationship between state ownership $(S O)$ and privatized firm performance $(F P)$ (Baron \& Kenny, 1986).

Finally, we implement estimation of marginal effects of the moderator by comparing firm's performance differences $(F P)$ as the value of the moderator changes (while keeping all other variables constant at their means).

\subsubsection{Propensity Score Matching}

The approach above is only valid when the moderator $(M)$ is randomly distributed. However, in practice, the government may assign privatized firms under the monitoring of SCIC according to specific characteristics of privatized firms. This "selection bias" may result in endogeneity issue of moderator $(M)$.

To fix the potential problem, we utilize the PSM technique to analyze the marginal effect of the moderator (SCIC) on privatized firm performance. Rosenbaum and Rubin (1983) proposed PSM technique as a tool to overcome selection bias in the estimation of treatment effects under non-randomized observational data sets.

Under this approach, observations in the treated group (i.e., the group that moderator $(M)$ is present) are aimed to match with the most alike observations in the control group (i.e., the group that moderator $(M)$ is not present). By this, each observation in the treated group is mirrored by an observation in the control group. Therefore, the differences in the outcome across matched pairs will reflect only the treatment effect of the moderator but not those observable differences.

The matching condition is as follows:

$$
\left(F P_{i l}, F P_{i 0}\right) \perp M_{i} \mid X_{i}
$$

where $\perp$ denotes independence, and $F P_{i l}$ denotes firm performance for observation $i$ if the treatment occurs $\left(M_{i}=1\right)$ and $F P i 0$ denotes firm performance if the treatment does not occur $\left(M_{i}=0\right)$. This implies that given observable control characteristics $(X)$, assignment to the treatment group is randomly distributed and is independent of firm performance. 
The condition in (3) is possibly difficult to be met since $X i$ may involve high number of dimensions. However, Rosenbaum and Rubin (1983) demonstrated that the condition in (3) could be transformed utilizing the propensity score, which is $p i=\operatorname{Pr}(M i \mid X i)$ where $p i$ denotes the probability of being treated given the observable characteristics $X$ and can be achieved by a logit or probit regression model. Thus, the equation (3) is developed into the following equation:

$$
\left(F P_{i l}, F P_{i 0}\right) \perp M_{i} \mid p_{i}
$$

In the next step, treated and untreated observations are matched on their propensity scores. There are several matching algorithms could be used. In this study, we utilize single nearestneighbor matching. Under this algorithm, an observation in the treatment group is matched with one other observation in the control group with the closest distance between their two propensity scores (Rosenbaum \& Rubin, 1983).

Finally, the average treatment effect on the treated (ATT) is achieved by

$$
A T T=E[F P(1)-F P(0) \mid M=1]
$$

\subsection{Variables Description}

\subsubsection{Firm Performance}

First, this study assessed the impact of residual state ownership on privatized firm performance via firm profitability proxied by ROA (Boubakri et al., 2005; Chen, Firth, \& Rui, 2006; Le \& Buck, 2011; Zengji, Abraham, \& Jun, 2016). Also, we used earnings before tax to calculate profitability ratios. The income before tax used aims to remove the effect of favorable tax policies that may be applied in some cases such as the tax incentives for new technology investment projects. Second, privatized firm performance is measured by its market performance proxied by Tobin's Q (Ang \& Ding, 2006; Beuselinck, Cao, Deloof, \& Xia, 2017; Boubakri et al., 2018; Liao \& Young, 2012; Tian \& Estrin, 2008; Wu, Wu, \& Rui, 2012; Yu, 2013).

\subsubsection{State Ownership}

This research imposes the percentage of state ownership announced among privatized firms as a measurement of state ownership (Ben-Nasr, Boubakri, \& Cosset, 2012; Beuselinck et al., 2017; Borisova, Fotak, Holland, \& Megginson, 2015; Haider, Liu, Wang, \& Zhang, 2018; Lin $\&$ Bo, 2012). However, this measurement of state ownership may potentially fail to capture the exact level of government control in privatized firms since privatized firms might be owned by entities that are partially owned or controlled by the state. This cross-ownership and pyramid control phenomena may result in under-estimating the precise impact of government control among privatized firms and this could be a potential limitation of our study.

\subsubsection{Moderating Variable}

In Vietnam, State Capital Investment Corporation (SCIC) represents state capital in privatized firms. It is expected that SCIC upholds the corporate governance in privatized firms, maximizes the value of state capital; thus, contributes positively to the performance of privatized firms. To investigate the moderating role of SCIC on the relationship between residual state ownership and privatized firm performance, we assigned the control of SCIC as a dummy variable. The dummy variable takes value of 1 if a privatized firm is under the control of SCIC, otherwise 0 .

\subsubsection{Control Variables}

\section{Managerial ownership}

Managerial ownership was considered as control variable since managerial ownership could enhance incentives of managers to pursue firm value maximization objectives and thus, increase the performance of firms (Ang, Cole, \& Lin, 2000; McKnight \& Weir, 2009; Singh \& Davidson III, 2003).

\section{Board ownership}

Similar to managerial ownership, the ownership of board members can enhance the incentives, increase the probability of disciplinary management turnover in poorly performing firms; consequently, it can help boost operating performance (Bhagat \& Bolton, 2008). Therefore, this study considered the level of ownership of board members as a control variable.

\section{Institutional ownership}

Institutional ownership is widely accepted to be an important corporate governance mechanism to mitigate agency problems and to improve firm performance. The advocates suggest that institutional investors have both ability, incentive, discipline, and resources to monitor and influence corporate managers. Shleifer and Vishny (1986) argued for the strong effect of monitoring by large shareholders especially institutional investors. There were also substantial evidence confirming the positive relationship between institutional ownership and firm performance (Elyasiani \& Jia, 2010; McConnell \& Servaes, 1990). Thus, we considered both domestic institutional ownership and foreign institutional ownership as control variables.

\section{Size}

Firm size was considered as a control variable in most of studies related to firm performance (Ang et al., 2000; 
Gedajlovic \& Shapiro, 2002). In this study, firm size is proxied by natural logarithm of total assets.

\section{Leverage}

There are many studies which demonstrate the relationship between capital structure and firm performance. According to the trade-off theory proposed by Kraus and Litzenberger (1973), a firm will have to trade off the costs and benefits of debt. The benefits of debt primarily originate from tax shields (Modigliani \& Miller, 1963) whereas the costs of debt are mainly driven by bankruptcy costs (in other words, financial distress costs) associated with firm's increasing financial risk as a result of interest payment. Financial leverage is measured by long term liabilities to common equity ratio.

\section{Industry}

The influence of industry characteristics on firm performance have been confirmed by previous studies. According to Dess, Ireland, and Hitt (1990), industry effects on performance should be measured and incorporated into management studies to mitigate misleading results. To control industry effects, we created industry dummies used to analyze the impact of residual state ownership on privatized firm performance.

\section{Year}

Due to economic cycle and time-variant factors, year effects may have an impact on the level of firm performance. Many studies have incorporated year effects when assessing the effect of state ownership on firms (Qi, Wu, \& Zhang, 2000; Yu, 2013). Following previous studies, this study also controls the year effects via utilizing year dummies in the research model.

\section{Exchange}

In the Vietnamese context, firms are listed on HNX and HSX. Each stock exchange has different regulations upon the requirements for firms to be listed. Thus, firms from different stock exchanges tend to have different characteristics. Therefore, our study also aims to control for stock exchange factor via utilizing exchange dummies.

\subsection{Data}

First, the data collected from Thomson Reuters are annual reports of 500 non-financial privatized firms listed on HSX and HNX during the period from 2007 to 2017. Next, observations with missing values were removed and trimming outliers were implemented via winsorizing extreme (1st and 99th) percentiles of ROA, Tobin's Q, firm size, and leverage to exclude the effect of outliers. Finally, a dataset comprising of 4146 firm-year observations was achieved as described in Table 1.

This table reports descriptive statistics of variables used in this study. The term $\mathrm{SO}$ is state ownership (\%); $\mathrm{MO}$ is managerial ownership (\%); BO is board ownership (\%); DIO is domestic institutional ownership (\%); FIO is foreign institutional ownership (\%); SIZE is natural logarithm of total assets; LEV is liabilities to equities ratio; ROA is returns on assets (\%) and Q is Tobin's Q.

Table 1: Descriptive statistics of variables

\begin{tabular}{|l|c|c|c|c|c|c|c|c|}
\hline Variable & $\mathbf{N}$ & Mean & S.D. & Min & p25 & p50 & p75 & Max \\
\hline SO & 4146 & 30.24 & 24.76 & 0.00 & 0.00 & 30.36 & 51.00 & 96.72 \\
\hline MO & 4146 & 3.40 & 6.77 & 0.00 & 0.09 & 0.81 & 3.41 & 64.99 \\
\hline BO & 4146 & 6.62 & 10.29 & 0.00 & 0.25 & 2.11 & 8.84 & 93.52 \\
\hline DIO & 4146 & 10.08 & 18.18 & 0.00 & 0.00 & 0.00 & 11.52 & 88.44 \\
\hline FIO & 4146 & 2.82 & 7.76 & 0.00 & 0.00 & 0.00 & 0.00 & 57.19 \\
\hline SIZE & 4070 & 26.90 & 1.35 & 23.78 & 25.96 & 26.84 & 27.83 & 30.80 \\
\hline LEV & 4072 & 1.63 & 1.57 & 0.04 & 0.51 & 1.16 & 2.19 & 9.91 \\
\hline ROA & 4068 & 8.03 & 7.50 & -15.05 & 2.73 & 6.57 & 11.80 & 37.12 \\
\hline Q & 4088 & 1.09 & 0.46 & 0.39 & 0.84 & 0.97 & 1.19 & 3.70 \\
\hline
\end{tabular}




\section{Empirical Results}

\subsection{Quadratic Regressions with Interactive Terms}

Table 2 provides the results of the quadratic regressions of privatized firm performance against state ownership. Model 1 and 3 indicate an inverted U-shaped relationship between residual state ownership and privatized firm performance as the coefficients of state ownership are positive and significant whereas the coefficients of square of state ownership are negative and significant. Specifically, model 1 and 3 indicates that when state ownership rises from 0 percent to 50 percent, ROA and Tobin's Q increase from 6.8699 percent to 8.9075 percent and from 1.0101 to 1.1523 , respectively. Contrarily, when state ownership climbs further from 50 percent to 100 percent, ROA and Tobin's Q drop from 8.9075 percent to 7.1781 percent and from 1.1523 to 1.0132 , respectively. This result confirmed the findings of studies indicating an inverted U-shaped relationship between residual state ownership and firm performance in the context of Vietnam and other East Asian countries. Boubakri et al. (2018); Hoang, Nguyen, and Hu (2017); Le, Pieri, and Zaninotto (2019); Nguyen and Vo (2020). Model 2 and 4 confirm the moderating effect of SCIC on the relationship between residual state ownership and privatized firm performance as both the interaction between state ownership and SCIC and the interaction between square of state ownership and SCIC are significant. This finding supports our proposed hypothesis.

The Model 1, 2, 3 and 4 simultaneously reveal the positive and significant impact of managerial ownership, domestic institutional ownership, and foreign institutional ownership on privatized firm performance. Specifically, Model 2 reveals that 1 percentage point increases in managerial ownership, domestic institutional ownership and foreign institutional ownership enhances the ROA of privatized firms by 0.0770 , 0.0296 and 0.0400 percentage points, respectively. Similarly, Model 4 indicates that 1 percentage point increase in managerial ownership, domestic institutional ownership and foreign institutional ownership also leads to an increase in Tobin's Q by $0.0033,0.0028$ and 0.0047 , respectively. These findings are consistent with the findings of previous studies (Ang et al., 2000; Bhagat \& Bolton, 2008; Elyasiani \& Jia, 2010; Nguyen, Nguyen, Ngo, \& Nguyen, 2019). This confirms that managerial ownership and institutional ownership are important factors in enhancing the performance of privatized firms during the post-privatization period.

Table 2: Quadratic regression models with interactive terms

\begin{tabular}{|l|c|c|c|c|}
\hline \multirow{2}{*}{ Variable } & \multicolumn{2}{|c|}{ ROA (\%) } & \multicolumn{2}{c|}{ Tobin's Q } \\
\cline { 2 - 5 } & Model 1 & Model 2 & Model 3 & Model 4 \\
\hline State ownership & $0.0784^{* * *}$ & $0.0557^{* * *}$ & $0.0057^{* * *}$ & $0.0041^{* * *}$ \\
\hline Square of State ownership & $-0.0008^{* * *}$ & $-0.0005^{* *}$ & $-0.0001^{* * *}$ & $-0.00004^{* * *}$ \\
\hline Specialized monitoring body & & $-6.0903^{* * *}$ & & $-0.4935^{* * *}$ \\
\hline $\begin{array}{l}\text { State ownership x Specialized } \\
\text { monitoring body (SCIC) }\end{array}$ & & $0.4679^{* * *}$ & & $0.0324^{* * *}$ \\
\hline $\begin{array}{l}\text { Square of state ownership x } \\
\text { Specialized monitoring body (SCIC) }\end{array}$ & & $-0.0060^{* * *}$ & & $-0.0004^{* * *}$ \\
\hline Managerial ownership & $0.0791^{* * *}$ & $0.0770^{* * *}$ & $0.0035^{* *}$ & $0.0033^{* *}$ \\
\hline Board ownership & -0.0115 & -0.0111 & 0.0010 & 0.0010 \\
\hline Domestic institutional ownership & $0.0307^{* * *}$ & $0.0296^{* * *}$ & $0.0029^{* * *}$ & $0.0028^{* * *}$ \\
\hline Foreign institutional ownership & $0.0473^{* * *}$ & $0.0400^{* * *}$ & $0.0052^{* * *}$ & $0.0047^{* * *}$ \\
\hline Size & 0.0822 & 0.0572 & $0.0337^{* * *}$ & $0.0325^{* * *}$ \\
\hline Leverage & $-1.8402^{* * *}$ & $-1.8194^{* * *}$ & $-0.0198^{* * *}$ & $-0.0178^{* * *}$ \\
\hline Industry dummies & Yes & Yes & Yes & Yes \\
\hline Year dummies & Yes & Yes & Yes & Yes \\
\hline Exchange dummies & Yes & Yes & Yes & Yes \\
\hline Constant & $10.3993^{* * *}$ & $11.3099^{* * *}$ & $1.3026^{* * *}$ & $1.3604^{* * *}$ \\
\hline R & 0.3591 & 0.3651 & 0.4233 & 0.4337 \\
\hline $\mathrm{N}$ & 3,927 & 3,927 & 3,946 & 3,946 \\
\hline
\end{tabular}

This table reports quadratic regressions with interactive terms of privatized firm performance proxied by ROA (\%) and Tobin's $Q$ on state ownership and variables defined in sub-section 3.2. ${ }^{*}$ denotes $p$-value $<0.10$; ${ }^{* *}$ denotes $p$-value $<0.05$; and ${ }^{* * *}$ denotes $p$-value $<0.01$. 
Table 3: Marginal effect of SCIC on privatized firm performance under quadratic regression models with interactive terms

\begin{tabular}{|c|c|c|c|c|c|c|}
\hline & Margin & Std. Err. & $\mathbf{t}$ & $P>t$ & \multicolumn{2}{|c|}{ 95\% Confident Interval } \\
\hline \multicolumn{7}{|c|}{ Marginal Effect of SCIC on ROA (\%) } \\
\hline $\mathrm{SCIC}=0$ & 8.2675 & 0.1811 & 45.6600 & 0.0000 & 7.9125 & 8.6225 \\
\hline $\mathrm{SCIC}=1$ & 10.8041 & 0.4788 & 22.5700 & 0.0000 & 9.8654 & 11.7427 \\
\hline \multicolumn{7}{|c|}{ Marginal Effect of SCIC on Tobin's $Q$} \\
\hline $\mathrm{SCIC}=0$ & 1.1122 & 0.0105 & 106.3500 & 0.0000 & 1.0917 & 1.1327 \\
\hline $\mathrm{SCIC}=1$ & 1.2659 & 0.0280 & 45.2600 & 0.0000 & 1.2111 & 1.3208 \\
\hline
\end{tabular}

This table reports marginal effect of the monitoring body $(\mathrm{SCIC})$ on privatized firm performance under quadratic regression models with interactive terms.

Table 4: Average treatment effect of specialized monitoring body (SCIC) on privatized firm performance

\begin{tabular}{|l|c|c|c|c|c|c|}
\hline Variable & Sample & Treated & Controls & Difference & S.E. & T-stat \\
\hline \multirow{2}{*}{ ROA (\%) } & Unmatched & 10.6495 & 7.2595 & 3.3900 & 0.4112 & 8.2400 \\
\cline { 2 - 7 } & ATT & 10.6495 & 8.3560 & 2.2935 & 1.0339 & 2.2200 \\
\hline \multirow{2}{*}{ Tobin's Q } & Unmatched & 1.2370 & 1.0576 & 0.1794 & 0.0249 & 7.2000 \\
\cline { 2 - 7 } & ATT & 1.2370 & 1.1150 & 0.1220 & 0.0650 & 1.8800 \\
\hline
\end{tabular}

This table reports average treatment effect of the monitoring body $(\mathrm{SCIC})$ on privatized firm performance using propensity score matching technique.

In addition, firm size is positively associated with privatized firm market performance, proxied by Tobin's Q, as a $1 \%$ increase in total assets causes Tobin's $Q$ to increase by 0.0003 . On the contrary, leverage is shown to have a negative relationship with privatized firm financial performance and market performance, as an increase in financial leverage by $1 \%$ results in a decrease of 1.8194 percentage points in ROA and a drop of 0.0178 in Tobin's Q (Dang, Nguyen, \& Tran, 2020; Le \& Phan, 2017) (see Table 2).

The marginal effect of SCIC on privatized firm performance is depicted in Table 3. The results reveal that when keeping other variables fixed at their means, changing from 'not under SCIC control' to 'under SCIC control' drags the ROA and Tobin's Q of privatized firms from 8.2675 percent to 10.8041 percent and from 1.1122 to 1.2659 , respectively. These results confirm the moderating role of SCIC control variable that increases the impact of state ownership on privatized firm performance significantly.

\subsection{Propensity Score Matching}

It is noted that our study's results may encounter selection bias as the government may choose to assign privatized firms under SCIC control in accordance with their specific characteristics. In other words, privatized firms under the control of SCIC are not randomly selected. To deal with the potential selection bias, we utilized the PSM technique to estimate the marginal effect of SCIC monitor on privatized firm performance. Therein, privatized firms under the control of SCIC are matched with privatized firms not under the control of SCIC via observable characteristics including firm size, firm capital structure, industry effect, exchange effect, year effect, state ownership, managerial ownership, board ownership, domestic institutional ownership and foreign institutional ownership.

Table 4 below indicates the results of the average treatment effect on the treated group which includes all privatized firms under the control of SCIC (SCIC $=1)$. All the t-stat value is higher than 1.96; this affirms the significant impact of SCIC on firm performance. If we go into details, we will find that, among privatized firms, the SCIC on an average, raises ROA from 8.3560 percent to 10.6495 percent and Tobin's Q from 1.1150 to 1.2370 . This result is close to results generated in sub-section 4.1 which suggests the generally positive role of SCIC on the performance of privatized firms (see Table 4).

\section{Discussion}

In the Vietnamese context, the State Capital Investment Corporation (SCIC) acts as a representative of state capital in privatized firms. SCIC is established with an aim to enhance the efficiency of state capital invested there. To some extent, SCIC shares some similar characteristics of a sovereign wealth fund since this institution tends to behave as an active shareholder to achieve the pure goal of maximizing the return on the invested capital by the government. However, 
SCIC is slightly different to sovereign wealth funds in other countries, since SCIC is also responsible for restructuring, privatizing SOEs and consulting on corporate governance of privatized firms.

Our study's findings provided empirical results that indicated the moderating role of SCIC in the relationship between residual state ownership and firm performance among privatized firms. Also, the results confirmed that privatized firms under the control of SCIC experience higher profitability and higher market performance. Our study also found that among privatized firms, SCIC may potentially improve ROA by $2.2935-2.5366$ percentage points and the Tobin's Q by $0.1220-0.1537$.

The positive impact of SCIC on firm performance could be explained by (i) SCIC is concerned about wealth generation of privatized firms more than other line ministerial and provincial authorities; (ii) transferring control of privatized firms to SCIC frees the government ministries in functioning as the management of privatized firms, and it separates government functions from enterprise management which may lead to better governance practices and (iii) by acting solely as a shareholder, SCIC may eliminate the soft budget constraint issue and introduce 'market mechanisms' into privatized firms.

In comparison to the global context, the SCIC of Vietnam shares some similarities with the State-Owned Assets Supervision and Administration Commission (SASAC) of China. The results of our study are also partly consistent with Wang, Guthrie, and Xiao (2012) which implies the positive role of SASAC in easing the downsides of governmental ownership. These results imply that the separation of governmental functions from the management of privatized firms could enhance the performance of SOEs in transitional economies.

\section{Conclusion}

Our study discovers a positive moderating role for specialized government monitoring body on the relationship between residual state ownership and privatized firm performance. Empirical results demonstrate that privatized firms under the control of specialized monitoring body outperform their peers. By setting up one specialized government monitoring body and separating the governmental management from business management of privatized firms, the government may lessen government intervention in privatized firms' management and maximize the alignment of wealth maximization objectives between state shareholders and non-state shareholders in privatized firms. In this context, the specialized government monitoring body acts purely as an active and strategic shareholder to assure the efficient utilization of state assets in privatized firms and remove management team in case of poor performance.

\section{References}

Abdallah, A. A. N., \& Ismail, A. K. (2017). Corporate governance practices, ownership structure, and corporate performance in the GCC countries. Journal of International Financial Markets, Institutions \& Money, 46, 98-115. doi:10.1016/j. intfin.2016.08.004

Aguilera, R. V., \& Jackson, G. (2010). Comparative and International Corporate Governance. The Academy of Management Annals, 4(1), 485-556. doi:10.1080/19416520.2010.495525

Ang, J. S., Cole, R. A., \& Lin, J. W. (2000). Agency costs and ownership structure. Journal of Finance, 55(1), 81-106. doi:10.1111/0022-1082.00201

Ang, J. S., \& Ding, D. K. (2006). Government ownership and the performance of government-linked companies: The case of Singapore. Journal of Multinational Financial Management, 16(1), 64. doi:10.1016/j.mulfin.2005.04.010

Baron, R. M., \& Kenny, D. A. (1986). The moderator-mediator variable distinction in social psychological research: Conceptual, strategic, and statistical considerations. Journal of Personality and Social Psychology, 51(6), 1173-1182. doi:10.1037/0022-3514.51.6.1173

Ben-Nasr, H., Boubakri, N., \& Cosset, J. C. (2012). The political determinants of the cost of equity: Evidence from newly privatized firms. Journal of Accounting Research, 50(3), 605-646. doi:10.1111/j.1475-679X.2011.00435.x

Bennedsen, M. (2000). Political ownership. Journal of Public Economics, 76(3), 559-581. doi:10.1016/S00472727(99)00096-1

Beuselinck, C., Cao, L., Deloof, M., \& Xia, X. (2017). The value of government ownership during the global financial crisis. Journal of Corporate Finance, 42, 481-493. doi:10.1016/j. jcorpfin.2015.05.002

Bhagat, S., \& Bolton, B. (2008). Corporate governance and firm performance. Journal of Corporate Finance, 14(3), 257-273. https://doi.org/10.1016/j.jcorpfin.2008.03.006

Bo, H., Li, T., \& Toolsema, L. A. (2009). Corporate social responsibility investment and social objectives: An examination on social welfare investment of Chinese state-owned enterprises. Scottish Journal of Political Economy, 56(3), 267-295. doi:10.1111/j.1467-9485.2009.00484.x

Borisova, G., Fotak, V., Holland, K., \& Megginson, W. L. (2015). Government ownership and the cost of debt: Evidence from government investments in publicly traded firms. Journal of Financial Economics, 118(1), 168-191. doi:10.1016/j. jfineco.2015.06.011

Bortolotti, B., \& Faccio, M. (2009). Government Control of Privatized Firms. The Review of Financial Studies, 22(8), 2907-2939. doi:10.1093/rfs/hhn077 
Boubakri, N., Cosset, J.C., \& Guedhami, O.(2005). Postprivatization corporate governance: The role of ownership structure and investor protection. Journal of Financial Economics, 76(2), 369-399. doi:10.1016/j.jfineco.2004.05.003

Boubakri, N., El Ghoul, S., Guedhami, O., \& Megginson, W. L. (2018). The market value of government ownership. Journal of Corporate Finance, 50, 44-65. doi:10.1016/j. jcorpfin.2017.12.026

Boycko, M., Shleifer, A., \& Vishny, R. W. (1996). A theory of privatisation. The Economic Journal, 106(435), 309-319. doi: $10.2307 / 2235248$

Chen, C. C. (2013). Corporate Governance of State-Owned Enterprises: An Empirical Survey of the Model of Temasek Holdings in Singapore. Emerging Markets Economics: Firm Behavior \& Microeconomic Issues eJournal.

Chen, G., Firth, M., \& Rui, O. (2006). Have China's enterprise reforms led to improved efficiency and profitability? Emerging Markets Review, 7(1), 82-109. doi:10.1016/j. ememar.2005.05.003

Chien-Chung, L. (2012). The Chinese independent director mechanism under changing macro political-economic setting: A review of its first decade and two possible models for the future. American University Business Law Review, 1(2), 336.

Dang, H. N., Nguyen, T. T. C., \& Tran, D. M. (2020). The Impact of Earnings Quality on Firm Value: The Case of Vietnam. Journal of Asian Finance, Economics and Business, 7(3), 63-72. https://doi.org/10.13106/jafeb.2020.vo17.no3.63

Denis, D. K. (2001). Twenty five years of corporate governance research ... and counting. Review of Financial Economics, 10(3), 191-212. doi:10.1016/S1058-3300(01)00037-4

Dess, G. G., Ireland, R. D., \& Hitt, M. A. (1990). Industry effects and strategic management research. Journal of Management, 16(1), 7-27. doi:10.1177/014920639001600102

Elyasiani, E., \& Jia, J. (2010). Distribution of institutional ownership and corporate firm performance. Journal of Banking and Finance, 34(3), 606-620. doi:10.1016/j.jbankfin.2009.08.018

Gedajlovic, E., \& Shapiro, D. M. (2002). Ownership structure and firm profitability in Japan. The Academy of Management Journal, 45(3), 565-575. doi:10.2307/3069381

Haider, Z. A., Liu, M., Wang, Y., \& Zhang, Y. (2018). Government ownership, financial constraint, corruption, and corporate performance: International evidence. Journal of International Financial Markets, Institutions \& Money, 53, 76-93. doi:10.1016/j.intfin.2017.09.012

He, T., Li, W., \& Tang, G. (2012). Dividends Behavior in StateVersus Family-Controlled Firms: Evidence from Hong Kong. Journal of Business Ethics, 110(1), 97-112. doi:10.1007/ s10551-011-1150-0

Hoang, L. T., Nguyen, C. C., \& Hu, B. (2017). Ownership structure and firm performance improvement: Does it matter in the Vietnamese stock market? Economic Papers: A Journal of Applied Economics and Policy, 36(4), 416-428. doi:10.1111/1759-3441.12185
Holland, K. (2019). Government investment in publicly traded firms. Journal of Corporate Finance, 56, 319-342. doi:10.1016/j. jcorpfin.2019.01.004

Hu, Y., \& Izumida, S. (2009). The Relationship between Ownership and Performance: A Review of Theory and Evidence. International Business Research, 1(4). doi:10.5539/ibr. v1n4p72

Jensen, M. C., \& Meckling, W. H. (1976). Theory of the firm: Managerial behavior, agency costs and ownership structure. Journal of Financial Economics, 3(4), 305-360.

Kamal, M. (2010). Corporate governance and state-owned enterprises: A study of Indonesia's code of corporate governance. Journal of International Commercial Law and Technology, 5(4), 224.

Kim, H., \& Chung, K. H. (2018). Can state-owned holding (SOH) companies improve SOE performance in Asia? Evidence from Singapore, Malaysia and China. Journal of Asian Public Policy, 11(2), 206-225. doi:10.1080/17516234.2018.1450624

Kraus, A., \& Litzenberger, R. H. (1973). A state-preference model of optimal financial leverage. The Journal of Finance, 28(4), 911-922. doi: $10.2307 / 2978343$

Kuznetsov, P., \& Muravev, A. (2001). State Holding Companies as a Mechanism for Managing Enterprises in the State Sector. Problems of Economic Transition, 44(4), 49-69. doi:10.1080/1 0611991.2001 .11049761

Laffont, J., \& Tirole, J. (1991). Privatization and incentives. Journal of Law, Economics, \& Organization, 7, 84-105.

Le, M. D., Pieri, F., \& Zaninotto, E. (2019). From central planning towards a market economy: The role of ownership and competition in Vietnamese firms' productivity. Journal of Comparative Economics, 47(3), 693-716. https://doi. org/10.1016/j.jce.2019.04.002

Le, T., \& Buck, T. (2011). State ownership and listed firm performance: A universally negative governance relationship? Journal of Management \& Governance, 15(2), 227-248. doi:10.1007/s10997-009-9098-5

Le, T. P. V., \& Phan, T. B. N. (2017). Capital structure and firm performance: Empirical evidence from a small transition country. Research in International Business and Finance, 42, 710-726. doi:10.1016/j.ribaf.2017.07.012

Li, L., McMurray, A., Sy, M., \& Xue, J. (2018). Corporate ownership, efficiency and performance under state capitalism: Evidence from China. Journal of Policy Modeling, 40(4), 747-766. doi:10.1016/j.jpolmod.2018.03.002

Li, S., \& Xia, J. (2008). The Roles and Performance of State Firms and Non-State Firms in China's Economic Transition. World Development, 36(1), 39-54. doi:10.1016/j. worlddev.2007.01.008

Liao, J., \& Young, M. (2012). The impact of residual government ownership in privatized firms: New evidence from China. Emerging Markets Review, 13(3), 338-351. doi:10.1016/j. ememar.2012.02.004 
Lin, H.-C. M., \& Bo, H. (2012). State-ownership and financial constraints on investment of Chinese-listed firms: New evidence. The European Journal of Finance, 18(6), 497-513. doi:10.1080/1351847X.2011.611523

Liu, N., Wang, L., Zhang, M., \& Zhang, W. (2012). Government intervention and executive compensation contracts of stateowned enterprises: Empirical evidence from China. Journal of Chinese Economic and Business Studies, 10(4), 391-411. doi:1 0.1080/14765284.2012.724983

Loc, T. D., Lanjouw, G., \& Lensink, R. (2006). The impact of privatization on firm performance in a transition economy. Economics of Transition, 14(2), 349-389. doi:10.1111/j.14680351.2006.00251.x

Loch, M., Marcon, R., Pruner Da Silva, A. L., \& Xavier, W. G. (2018). Government's impact on the financial performance of electric service providers as both regulator and shareholder. Utilities Policy, 55, 142-150. doi:10.1016/j.jup.2018.09.007

McConnell, J. J., \& Servaes, H. (1990). Additional evidence on equity ownership and corporate value. Journal of Financial Economics, 27(2), 595-612. doi:10.1016/0304405X(90)90069-C

McKnight, P. J., \& Weir, C. (2009). Agency costs, corporate governance mechanisms and ownership structure in large UK publicly quoted companies: A panel data analysis. Quarterly Review of Economics and Finance, 49(2), 139-158. doi:10.1016/j.qref.2007.09.008

Megginson, W. L. (2017). Privatization, state capitalism, and state ownership of business in the 21 st century. Foundations and Trends in Finance, 11(1-2), 1-153.

Megginson, W. L., Nash, R. C., \& Randenborgh, M. (1994). The financial and operating performance of newly privatized firms: An international empirical analysis. Journal of Finance, 49(2), 403-452. doi:10.1111/j.1540-6261.1994. tb05147.x

Megginson, W. L., \& Netter, J. M. (2001). From state to market: A survey of empirical studies on privatization. Journal of Economic Literature, 39(2), 321-389. doi:10.1257/jel.39.2.321

Modigliani, F., \& Miller, M. H. (1963). Corporate income taxes and the cost of capital: A correction. The American Economic Review, 53(3), 433-443.

Nem Singh, J., \& Chen, G. C. (2018). State-owned enterprises and the political economy of state-state relations in the developing world. Third World Quarterly, 39(6), 1077-1097. doi:10.1080/ 01436597.2017.1333888

Ngo, M. T., Nonneman, W., \& Jorissen, A. (2014). Government ownership and firm performance: The case of Vietnam. International Journal of Economics and Financial Issues, 4(3), 628-650.

Ngo, M. T., Nonneman, W., \& Jorissen, A. (2015). Privatization of Vietnamese firms and its effects on firm performance. Asian Economic and Financial Review, 5(2), 202-217. doi:10.18488/ journal.aefr/2015.5.2/102.2.202.217
Nguyen, D. T., Nguyen, T. P., \& Nguyen, J. D. K. (2012). Vietnam's SCIC: A gradualist approach to sovereign wealth funds. Journal of the Asia Pacific Economy, 17(2), 268-283. doi:10.1080/135 47860.2012.668065

Nguyen, M. H., \& Vo, Q. T. (2020). Investigating the Association betweenResidualStateOwnershipandPrivatizedFirmEfficiency. Journal of Asian Finance, Economics and Business, 7(5), 225-236.https://doi.org/10.13106/jafeb.2020.vol7.no5.225

Nguyen, P. A., Nguyen, A. H., Ngo, T. P., \& Nguyen, P. V. (2019). The Relationship between Productivity and Firm's Performance: Evidence from Listed Firms in Vietnam Stock Exchange. Journal of Asian Finance, Economics and Business, 6(3), 131-140. https://doi.org/10.13106/jafeb.2019.vol6. no3.131

Nurgozhayeva, R. (2017). State ownership in terms of transition: Curse or blessing?. Cornell International Law Journal, 50(1), 76.

Panda, B., \& Leepsa, N. M. (2017). Agency theory: Review of Theory and Evidence on Problems and Perspectives. Indian Journal of Corporate Governance, 10(1), 74-95. doi:10.1177/0974686217701467

Peng, M., Bruton, G., Stan, C., \& Huang, Y. (2016). Theories of the (state-owned) firm. Asia Pacific Journal of Management, 33(2), 293-317. doi:10.1007/s10490-016-9462-3

Porta, R., Lopez-De-Silanes, F., \& Shleifer, A. (1999). Corporate Ownership Around the World. Journal of Finance, 54(2), 471517. doi:10.1111/0022-1082.00115

Qi, D., Wu, W., \& Zhang, H. (2000). Shareholding structure and corporate performance of partially privatized firms: Evidence from listed Chinese companies. Pacific-Basin Finance Journal, 8(5), 587-610. doi:10.1016/S0927-538X(00)00013-5

Rosenbaum, P. R., \& Rubin, D. B. (1983). The central role of the propensity score in observational studies for causal effects. Biometrika, 70(1), 41-55. doi:10.2307/2335942

Sam, C. Y. (2007). Partial privatization, corporate governance, and the role of state-owned holding companies. Journal of the Asia Pacific Economy, 13(1), 63-88. doi:10.1080/13547860701731895

Sam, C. Y. (2013). Partial privatisation and the role of state owned holding companies in China. Journal of Management \& Governance, 17(3), 767-789. doi:10.1007/s10997-011-9190-5

Sheshinski, E., \& López-Calva, L. (2003). Privatization and its benefits: Theory and evidence. CESifo Economic Studies, 49(3), 429-460. doi:10.1093/cesifo/49.3.429

Shleifer, A., \& Vishny, R. (1986). Large shareholders and corporate control. The Journal of Political Economy, 94(3), 461. doi: $10.1086 / 261385$

Shleifer, A., \& Vishny, R. W. (1997). A survey of corporate governance (Vol. 52, pp. 737-783). Oxford, UK: Oxford University Press.

Singh, M., \& Davidson III, W. N. (2003). Agency costs, ownership structure and corporate governance mechanisms. Journal of 
Banking and Finance, 27(5), 793-816. doi:10.1016/S03784266(01)00260-6

Souza, J., Megginson, W., \& Nash, R. (2005). Effect of institutional and firm-specific characteristics on post-privatization performance: Evidence from developed countries. Journal of Corporate Finance, 11(5), 747-766. doi:10.1016/j. jcorpfin.2004.12.001

Souza, J., \& Megginson, W. L. (1999). The financial and operating performance of privatized firms during the 1990s. Journal of Finance, 54(4), 1397-1438. doi:10.1111/0022-1082.00150

Tian, L., \& Estrin, S. (2008). Retained state shareholding in Chinese PLCs: Does government ownership always reduce corporate value? Journal of Comparative Economics, 36(1), 74-89. doi:10.1016/j.jce.2007.10.003

Tirole, J. (1994). The internal organization of government. Oxford Economic Papers, 46(1), 1-29. doi:10.1093/oxfordjournals. oep.a042114

Wang, J., Guthrie, D., \& Xiao, Z. (2012). The rise of SASAC: Asset management, ownership concentration, and firm performance in China's capital markets. Management and Organization Review, 8(2), 253-281. doi:10.1111/j.1740-8784.2011.00236.x

Wang, L., \& Judge, W. (2012). Managerial ownership and the role of privatization in transition economies: The case of China. Asia Pacific Journal of Management, 29(2), 479-498. doi:10.1007/ s10490-010-9205-9
Wei, Z., Xie, F., \& Zhang, S. (2005). Ownership structure and firm value in China's privatized firms: 1991-2001. Journal of Financial and Quantitative Analysis, 40(1), 87-108. doi:10.1017/S0022109000001757

Wong, S. (2004). Improving Corporate Governance in SOEs: An Integrated Approach. Corporate Governance International, 7(2). Available at SSRN: https://ssrn.com/ abstract $=897121$

Wu, W., Wu, C., \& Rui, O. M. (2012). Ownership and the value of political connections: Evidence from China. European Financial Management, 18(4), 695-729. doi:10.1111/j.1468036X.2010.00547.x

Yin Sam, C. (2010). Globalizing Partially Privatized Firms in Singapore: The Role of Government as a Regulator and a Shareholder. Journal of Asian and African Studies, 45(3), 258273. doi: $10.1177 / 0021909610364778$

Yu, M. (2013). State ownership and firm performance: Empirical evidence from Chinese listed companies. China Journal of Accounting Research, 6(2), 75-87. doi:10.1016/j. cjar.2013.03.003

Zengji, S., Abraham, N., \& Jun, Y. (2016). Institutional environment, political connections of partial state ownership, and performance: An empirical study on listed private sector firms in China. International Journal of Social Economics, 43(8), 856-870. doi:10.1108/IJSE-10-2014-0210 